\title{
Portaria $\mathrm{n}^{\circ} 1$, de 3 de janeiro de 1947
}

No ano de 1947, o Diretor-Geral do Departamento de Educação professor Severino Bezerra de Melo - no uso de atribuições legais (Portaria $n^{\circ}$ 1, de 3 de janeiro de 1947) recomendava os títulos e os autores de livros e a série correspondente que deveriam ser então adotados nos Grupos Escolares, Escolas Reunidas e Escolas Isoladas. O Conselho Editorial da Revista Educação em Questão publica, nessa edição, a referida Portaria $n^{\circ}$ 1, de 3 de janeiro de 1947 cujo o teor segue transcrito abaixo:

Marta Maria de Araújo

Editora Responsável da Revista Educação em Questão

\section{Diário Oficial do Estado do Rio Grande do Norte Departamento de Educação Expediente do Diretor-Geral} Portaria $\mathrm{n}^{\circ} 1$, de 3 de janeiro de 1947

Diretor-Geral do Departamento de Educação, no uso de atribuições legais resolve recomendar que sejam adotados nos estabelecimentos oficiais de Ensino Primário no $1^{\circ}$ semestre de 1947, os seguintes livros:

\section{Grupos Escolares}

Série Moura Santos - O Pequeno Escolar

$1^{\circ}$ ano - Cartilha e $1^{\circ}$ grau - O Pequeno Escolar - Máximo Moura Santos.

$2^{\circ}$ ano $-2^{\circ}$ grau - $O$ Pequeno Escolar - Máximo Moura Santos.

$3^{\circ}$ ano $-3^{\circ}$ grau - $O$ Pequeno Escolar - Máximo Moura Santos.

$4^{\circ}$ ano $-4^{\circ}$ grau - O Pequeno Escolar - Máximo Moura Santos.

$5^{\circ}$ ano (Complementar) - Exames de admissão - Raja Gabaglia.

$5^{\circ}$ ano (Complementar) - Antologia Nosso Brasil - Hildebrando Lima.

$3^{\circ}$ e $4^{\circ}$ anos (livros auxiliares) - Pontos de Geografia e História - Gaspar de Freitas 
$3^{\circ}$ e $4^{\circ}$ anos (livros auxiliares) - Gramática Elementar - Eduardo Carlos Perreira. $3^{\circ}$ e $4^{\circ}$ anos (livros auxiliares) - Aritmética Elementar - Antônio Trajano.

\section{Escolas Reunidas}

Série Ligia de Moura Santos - O Bom Colegial

$1^{\circ}$ ano - Cartilha e $1^{\circ}$ livro - O Bom Colegial - Ligia de Moura Santos.

$2^{\circ}$ ano $-2^{\circ}$ livro - $O$ Bom Colegial - Ligia de Moura Santos.

$3^{\circ}$ ano $-3^{\circ}$ livro - $O$ Bom Colegial - Ligia de Moura Santos.

$4^{\circ}$ ano $-4^{\circ}$ livro - $O$ Bom Colegial - Ligia de Moura Santos.

$3^{\circ}$ e $4^{\circ}$ anos (livros auxiliares) - Pontos de Geografia e História - Gaspar de Freitas.

$3^{\circ}$ e $4^{\circ}$ anos (livros auxiliares) - Gramática Elementar - Eduardo Carlos Pereira. $3^{\circ}$ e $4^{\circ}$ anos (livros auxiliares) - Aritmética Elementar - Antônio Trajano.

\section{Escolas Isoladas}

$272 \quad 1^{\circ}$ ano - Cartilha das mães - Arnaldo de Oliveira Barreto.

$1^{\circ}$ ano - Vida na Roça - Thales Castanho de Andrade ( $1^{\circ}$ livro).

$2^{\circ}$ ano - Leituras Brasileiras - Nelson Costa (2 ${ }^{\circ}$ livro).

$3^{\circ}$ ano - As Férias no Pontal - Rodolfo Von Ihering ( $3^{\circ}$ grau Primário).

$3^{\circ}$ ano (livros auxiliares) - Pontos de Geografia e História - Gaspar de Freitas.

$3^{\circ}$ ano (livros auxiliares) - Gramática Elementar - Eduardo Carlos Pereira.

$3^{\circ}$ ano (livros auxiliares) - Aritmética Elementar - Antônio Trajano.

Para as noções de Moral, Civismo e Geometria, indispensável em todos os anos do curso primário, os professores organizarão ponto fáceis e práticos.

Poderão ser dados de $1^{\circ}$ ao $3^{\circ}$ ano Primário como exercício de leitura, tendo-se em conta a capacidade aquisitiva da classe, além das lições dos compêndios adotados, trechos interessantes escolhidos de bons autores, passados para o quadro negro e copiado pelos alunos. 
As escolas particulares de ensino primário e subvencionadas, deverão adotar, de acordo com o grau de rendimento dos alunos, os mesmos livros recomendados para os estabelecimentos oficiais.

Todas as livrarias de Natal já estão cientes da adoção desses compêndios. Os Senhores Inspetores de Ensino e Diretores de Grupos Escolares, Escolas Reunidas e Escolas Isoladas tomarão as necessárias providências para que sejam cumpridas as recomendações da presente Portaria.

Diretoria Geral do Departamento de Educação, Natal, 3 de janeiro de 1947. Severino Bezerra de Melo

Diretor-Geral do Departamento de Educação

RIO GRANDE DO NORTE. Portaria n ${ }^{\circ} 1$, de 3 de janeiro de 1947. Diário Oficial do Estado [do] Estado do Rio Grande do Norte, Natal, 5 jan. 1947. p. 3. 